\section{Upsetting apple-carts}

The British research establishment is ripe for a shake-up. Here is one recipe.

THE past year has been a bigger trauma for the British research community than even its immediate predecessors, dominated as they were by the dwindling value of the funds available for research. Now, perhaps not before time, structural change is in the air. Several unrelated issues have come to the boil at the same time. The Science and Engineering Research Council, with a new chairman and a substantially changed membership (see p. 756) must soon produce a plan for the years ahead that will give the largest of the research councils a coherence that will hold it together in the face of centripetal tendencies born of its complexity. The University Grants Committee is committed to a plan for concentrating financial support on the universities strongest in research, but neither the committee nor its dependants know how the system will work. The Advisory Board for the Research Councils (ABRC) is busily putting out fires where it can find them, and is for example embarked on an inquiry into the plight of the British Geological Survey, the largest single component of the Natural Environment Research Council (NERC), but seems not yet to have attempted the more urgently needed inquiry into its own constitution.

The immediate effect is that people in laboratories have been painfully reminded of the fate that has already befallen some thousands of researchers and academics, whose jobs have melted away in the past few years. But as the whole world knows, there is nothing so demoralizing as uncertainty. It is in everybody's interest that the changes now under way should be carried through quickly. Things have reached the point at which almost any decisions would be better than the continuing indecision that seems to grip the establishment. There is nothing new in the recipe for change that follows, most of which has been advocated in the past year or more. Other recipes might serve the same purpose. The need is that somebody should pick one of them and stick to it.

Money. The government has kept its promise of five years ago that research council budgets would stay constant, and there has even been some extra money for earmarked purposes such as information technology. It is intolerable that there should have been so little substantial help with the reorganization of laboratories forced on the Agricultural and Natural Environmental Research Councils in the past few years, for the government has thus allowed what it considers to have been past mistakes to cast a shadow over the health of the whole enterprise. But people had better learn to live with the notion that there will be no extra funds. But reorganization is necessary for other reasons than financial shortage.

Management. The touchstone for the past dozen years in the management of British civil science has been the Rothschild principle, by which government departments, proxy "customers" representing the interests of the end users of research, commission much of the work carried out in civil research establishments. That principle is now dead, as shown by the ease with which government departments have been able to walk away from research institutes they had previously supported. (The British Geological Survey is that most conspicuously left high and dry by departmental fickleness of this kind.) So there is a need for other mechanisms for supporting important and creative work. To detach some parts of the publicly supported research network altogether from the government would make sense. ("To privatize" is the fashionable verb.) The Plant Breeding Institute, perhaps the most immediately productive of the agricultural research council's establishments, is the obvious candidate if it were allowed also to enjoy the income generated by its findings through the National Seed Development Organization; why does nothing happen? But if the government hopes that the cost of public research could be drastically reduced by hiving off large chunks of it, that ambition should be suppressed. Nor is there as much hope as there may seem in schemes for encouraging parts of the research enterprise to compete for research contracts with private industry; the universities and private research organizations are now eagerly exploiting that market, the former at cut-price rates. Deciding what parts of the public research network to keep and to cherish, and what parts to close down, is an urgent need. Since many of the neglectful government departments are probably mistaken in their indifference to research, the British government corporately should take a view on the wisdom of transferring organizations such as the institutes responsible for geological survey and oceanography back to where they came from (the Department of the Environment and the Royal Navy, respectively).

Leadership. One of the contributory causes of the present decline of British science is that working scientists no longer have a sense that there is a powerful and influential group of people looking out for the well-being of their work. The heads of the research councils are mostly reasonable men, but are undemonstrative and, by tradition, are also anxious not to give the impression publicly that they seriously dissent from the way in which science is being managed, or mismanaged. The result is that they seem to their constituents more like civil servants than the spokesmen of their subcommittees. In the peculiarly British environment, the Royal Society might most suitably play this role. But would the task of helping to point the scientific enterprise in the right direction be feasible within the convention of politeness to which the society is committed?

Institution. Many of the organizations responsible for the direction of civil research in Britain have outlived their usefulness, or have reached the point where only substantial change will fit them for what emerges as their purpose. ABRC itself is a point at which reform should start. The council is too large to be a workable committee, and too representative of conflicting interests to be an effective way of settling contentious issues. To the extent that the council's function is to advise the Secretary of State for Education and Science, one man would suffice. To the extent that it is necessary to put forward the opinions of the users of what the research councils provide - that there should be some predetermined pattern of spending - a handful of outsiders would be the ideal. To the extent that the council should have a part to play in helping to understand what is happening to British research, there is a need for a more effective secretariat than at present. All this is roughly what Sir Douglas Hague, the chairman of the Economic and Social Research Council and one of the members of ABRC, was saying when he joined the council two years ago. Why have his fellow members not listened to what he was saying? And why have the same people not understood the case for disbanding NERC, the research council that had the bad luck to be set up with terms of reference too ambitious for the components with which it was endowed.

Coordination. One of the chief diseconomies in the present organization of research in Britain is that there is no way in which the different parts of the research enterprise can be meshed with each other. Defence research is an entity on its own (but change may be on the way). And separate government departments continue to maintain laboratories and research institutes which become, as morale sinks deeper, more separate from each other than they have ever been. The National Physical Laboratory, dependent on the Department of Trade and Industry, has been in its time a powerful stimulant of research in universities and elsewhere. It is still a worthy place, but much less a laboratory to be proud of. That, too, is a field ripe for reform.

On the face of things, it would be for the government to put these things to right, just as it has fallen to the government to decide what should next be done about the renegotiation of the British relationship with the European high-energy physics laboratory (CERN) at Geneva. But no doubt from depression, the country's capacity to make decisions seems to have been undermined. The notion that any decision is better than indecision is, of course, dangerous; it provides a licence for foolishness. That is why the scientific community itself should find some way of taking charge of events, such as they are. 